\title{
Small mammals on one-year set-aside
}

\author{
Françoise H. TATTERSALL, David W. MACDONALD, Will J. MANLEY, \\ Simon GATES, Ruth FEBER and Barbara J. HART
}

\begin{abstract}
Tattersall F. H., Macdonald D. W., Manley W. J., Gates S., Feber R. and Hart B. J. 1997. Small mammals on one-year set-aside. Acta Theriologica 42: 329-334.

Despite its conservation potential, little is known of whether land taken out of arable production as set-aside benefits wildlife, nor what features enhance its value as a habitat. We studied the presence of small mammals on one-year set-aside through a summer harvest period (278 captures in 3000 trap nights). Trapping success was low on all set-aside $(0.6 \%)$, but was higher in adjoining hedgerow $(30 \%)$ and cereal crops (13\%). Wood mice Apodemus sylvaticus (Linnaeus, 1758) were the most commonly caught species, and the only species to occur on set-aside. There were no significant differences in trap success between set-aside configured in blocks and strips, nor between sown and naturally regenerated set-aside. Captures on set-aside increased after harvest, when the crop no longer provided cover. Our data demonstrate that set-aside is not necessarily a suitable habitat for small mammals.
\end{abstract}

School of Agriculture, Royal Agricultural College, Cirencester, GL7 6JS, UK (FHT, WJM, JH); Wildlife Conservation Research Unit, Department of Zoology, South Parks Road, Oxford, OX1 3PS, UK (DWM, SG, RF)

Keywords: Apodemus sylvaticus, set-aside, arable ecosystem

\section{Introduction}

Set-aside, whereby land is taken out of agricultural production, has been widely practiced in the USA for some time (Ervin 1992). Since the reform of the European Common Agricultural Policy in 1992, set-aside has become a widespread feature of the landscape of Britain and other European countries (Clarke 1992). In the 1996/97 season, EU farmers had to take at least $10 \%$ of their arable land out of production in order to qualify for arable area payments, and a total of 5616616 ha were put into set-aside in the EU (EC Commission, unpubl.). Set-aside, in its various manifestations, is thus a significant new land use within the arable ecosystems of Europe.

Despite the possible conservation benefits of set-aside (Firbank et al. 1993, 1994, MAFF 1995), and the potential political capital attached to them, only a handful of studies, mainly directed at birds, have specifically addressed the use 
of set-aside by vertebrate wildlife through field research in the UK (eg Boag 1992, Sears 1992, Blake and Dowell 1993, Grynderup Poulsen and Sotherton 1993, Sage and Robertson 1994, Rogers and Gorman 1995a, b, c). With few exceptions (eg Berg and Part 1994, Berner 1988), there has been even less such research elsewhere in Europe.

The environmental impact of set-aside is complicated by the management options open to farmers (MAFF 1995), and its consequent variability as wildlife habitat. Cover can be established by either sowing a non-harvestable grass or crop mixture, or by allowing natural regeneration from the seed bank which may result in large numbers of volunteer crops in the first year. In addition to whole fields, strips of land can be set aside, provided they are at least $20 \mathrm{~m}$ wide and 0.3 ha in area. Green cover must be established over winter to prevent leaching. Vegetation can be controlled by cutting or spraying with non-residual herbicides, and must be cut short or destroyed by the end of August. Use of insecticides and fungicides is banned. Set-aside can be left in place for as long as the farmer wishes, but in practice is often put back into cereal production after one year $(63 \%$ of set-aside in 1994/95, $40 \%$ in 1995/96; EC Commission, unpubl.), particularly in countries such as the Netherlands $(79 \%)$ or Italy $(74 \%)$.

In Britain, the Ministry of Agriculture Fisheries and Food (MAFF) regulations set out the minimum that farmers need to do, although farmers are encouraged to manage their set-aside in an environmentally friendly manner (MAFF 1995). However, there has, as yet, been insufficient research to clearly establish what features, if any, of set-aside are good for wildlife, and for mammals in particular. We studied some aspects of the presence of small mammals on typically managed one-year set-aside at two farms in Gloucestershire, UK.

While many factors are likely to affect the attractiveness of set-aside to the small mammal community, three potential factors are: (a) configuration (block or strip); (b) establishment method (natural regeneration or sown); and (c) changes in availability of alternative habitats such as crop. We attempted to investigate the effects of these factors by surveying small mammal communities in sown and naturally regenerated strips and blocks of one-year set-aside, and in adjacent hedgerow and cereal crop, through the harvest cycle.

\section{Study area and methods}

We live-trapped small mammals at four sites on two farms, Coates and Harnhill Manor, at the Royal Agricultural College in Gloucestershire, UK. At each farm two sites ('A' and 'B') were trapped using grids of 50 Longworth live-traps set at approximately $12 \mathrm{~m}$ intervals. Traps were baited with wheat and fly pupae, and were checked twice a day, in the morning and afternoon. Animals were individually marked by fur-clipping. Trapping sessions lasted for five nights, once a month in June, July and August 1995.

Each trap site consisted of a central hedgerow about $4 \mathrm{~m}$ wide. On one side of each hedgerow was a $20 \mathrm{~m}$ field margin strip of set-aside adjoining a wheat (Harnhill) or barley (Coates) crop. The other 
side of each hedgerow consisted of either a whole field of wheat (A sites) or a whole field of set-aside (B sites). Whole-field set-aside at Harnhill B was naturally regenerated, and was dominated by field pansy Viola arvensis and field forget-me-not Myosotis arvensis and, in August, by knotgrass Polygonum aviculare. Elsewhere set-aside was sown with a mixture of wheat and oilseed rape. Set-aside had been established the previous autumn, and so was less than one year old when the study began, and cover was sparse on all set-aside.

At each site we set a grid of traps such that there were five rows of 10 traps: one row in the hedgerow, one row in the set-aside strip ( $12 \mathrm{~m}$ out from the hedge center), one row $2 \mathrm{~m}$ into the edge of the crop adjoining the set-aside strip and, on the other side of the hedge, two rows set $12 \mathrm{~m}$ and $24 \mathrm{~m}$ out in the crop (A sites) or whole-field set-aside (B sites).

Trapping covered two mowing operations on all the set-aside (in June and July) and harvest and ploughing on the crop fields. In July the barley adjoining set-aside strips at Coates was harvested and the stubble ploughed in, and by August all set-aside at Coates had been ploughed up, and the remaining wheat crop harvested. At Harnhill all crops were harvested at the end of July, leaving bare stubble and set-aside for the August trapping session.

We used trap success as an index of small mammal abundance with which to compare different habitats and months. Trap success was calculated as the percentage of trap nights $(n=3000)$ which were successful. We used this index, rather than an estimate of population density, for three reasons: the timing of farming operations on our study sites meant that we ended up with different numbers of trap-nights in each habitat, numbers of individuals were small, and we wanted a broad estimate of how much small mammals used set-aside rather than an estimate of the total number of animals, in which transients would have had an unduly large effect.

\section{Results and discussion}

Eight species were caught: wood mouse Apodemus sylvaticus (Linnaeus, 1758), yellow-necked mouse $A$. flavicollis, bank vole Clethrionomys glareolus, field vole Microtus agrestis, common shrew Sorex araneus, pygmy shrew S. minutus, water shrew Neomys fodiens, and house mouse Mus domesticus. Overall trap success was $9.3 \%$ (278 captures, 179 individuals), and wood mice (67 individuals), bank voles (38 individuals) and common shrews (66 individuals) were most frequently trapped, together comprising $91 \%$ of captures, with captures of wood mice predominating (39\% of all captures). Although all animals captured were in breeding condition, only two juvenile wood mice (both perforate females of $10 \mathrm{~g}$ ), and no juveniles of any other species, were caught.

In total only six captures (comprising five individual wood mice) occurred on set-aside, a trap success of $0.6 \%$. In comparison, relatively large numbers of all species were caught in hedgerow (29.5\% trap success), and moderate numbers (including two yellow-necked mice) in uncut cereal crops (12.7\%). Success was low on crop stubble (2\%), and no animals were caught on ploughed fields. Of the three commonest species, 26 individual common shrews and 28 individual wood mice were caught in the uncut crop, with trap successes of $5.8 \%$ and $5.6 \%$ respectively, and when released from traps escaped into extensive cracks in the soil surface. Apart from three captures (of three different individuals) in the crop, bank voles were found exclusively in the hedgerow. Only wood mice were caught on set-aside. 
Overall, trap success was significantly lower in whole fields of set-aside than in crops $\left(\chi^{2}=27.5, \mathrm{df}=1, p<0.001\right)$, and this led to A grids, encompassing mainly crop, having significantly greater overall trap success (13\% and $12 \%)$ than B grids ( $4 \%$ and $8 \%)$, encompassing mainly set-aside $\left(\chi^{2}=15.4, \mathrm{df}=1, p<0.001\right)$. There were no significant differences between the four grids in trap success in set-aside strips or crop edge adjoining set-aside strips. However, trap success in the hedgerow at Coates $\mathrm{B}$, which had more gaps than those elsewhere, was significantly lower than at other hedgerow sites $\left(\chi^{2}=8.5, \mathrm{df}=3, p<0.001\right)$.

Exactly equal numbers of individual wood mice were caught on blocks (three, $0.6 \%$ trap success) and field margin strips (three, $0.6 \%$ trap success) of set-aside. However, within the crop there was some evidence that the set-aside strip acted as a barrier to dispersal out of the hedgerow, when trap success of both wood mice and shrews together was considered: there were significant differences between trap rows $24 \mathrm{~m}$ out from the hedge in crop directly adjacent to hedgerow (17.2\% success) and in crop separated from the hedge by a set-aside strip ( $0.5 \%$ success, $\chi^{2}=29, \mathrm{df}=1, p<0.001$ ). This apparent barrier effect was not the result of higher densities towards the crop center because there was no significant difference between rows $12 \mathrm{~m}$ into the crop ( $15.2 \%$ success) and rows $24 \mathrm{~m}$ into the crop (17.2\% success).

There was, thus, no evidence that strips of one-year set-aside were more attractive to small mammals in our study area than blocks of one-year set-aside, nor did our results suggest that small mammals distinguished between sown and naturally regenerated set-aside. The method of establishment (sown or naturally regenerated) is probably not necessarily a good predictor of the final structural and floristic diversity, as many factors influence the nature of the final vegetation (Smith and Macdonald 1992).

The relative importance of blocks and strips of set-aside might change, however, with time of year, and vegetative composition, and will vary between species. Field voles, for example, are grassland specialists which might benefit more from large permanent blocks of set-aside than from one-year strips. Interpretation of our results with regard to the effect of configuration and establishment must be tempered by the lack of cover on set-aside at our study sites, and by our low capture rates for all species. We suspect that our low trap success was due to the overriding influence of poor cover (Plesner Jensen and Honess 1995) on both sown and naturally regenerated set-aside at our study sites.

All captures on set-aside during August occurred at Harnhill; by this time set-aside at Coates had been ploughed. During August at Harnhill B six wood mice were present in the central hedgerow, where previously only one individual had been found. High densities in the hedgerow, and the lack of cover elsewhere may have increased the attractiveness of set-aside to the mice. For example, one female at Harnhill B was present in the crop edge adjoining the set-aside strip in June and July, but during August was captured first in hedgerow and then in the set-aside block on the other side. 


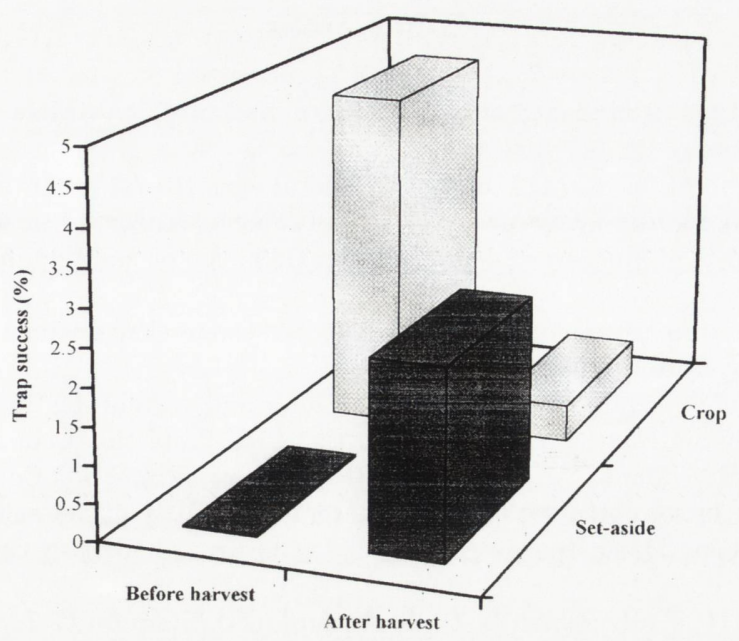

Fig. 1. Change in trapping success on set-aside and crop after harvest.

Of 16 wood mice captured more than three times, just over half (9) were captured entirely in the hedge. Of the five individuals that were captured in both hedge and crop only one moved from the crop edge and would have had to cross the set-aside. Four of the mice moved from the crop into hedgerow after harvest. Relative trap success for wood mice in set-aside and crops changed after harvest (Fig. 1). Trap success on set-aside increased statistically significantly after harvest (Exact test, $p=0.04$ ). In comparison to pre-harvest trap success, trap success for wood mice decreased significantly on cropped areas following harvest $\left(\chi^{2}=55.6\right.$, $\mathrm{df}=1, p<0.001$ ).

Conversely, however, where set-aside is cut before the crop there might be movement in the opposite direction, from set-aside to crop. The lack of alternative habitats could be one reason why Rogers and Gorman (1995a, b) caught fewer wood mice and other small mammals on a farm that had been entirely set aside than on a farm which was a mixture of set-aside, crop and semi-natural habitats.

The diversity and complexity of set-aside management regulations means that the value of set-aside as a habitat for even such a ubiquitous non-specialist as the wood mouse is highly variable. While older set-aside can hold moderate densities of small mammals (Rogers and Gorman 1995a), our data demonstrate that this is not necessarily the case for year-old set-aside.

Acknowledgments: This work was funded by MAFF. We are very grateful to R. Cartwright and P. Beattie for their assistance in the field, and we thank RAC Farms Director, M. Limb, and Farm Manager, T. Norris, for their help and co-operation. 


\section{References}

Berg A. and Part T. 1994. Abundance of breeding farmland birds on arable and set-aside fields at forest edges. Ecography 17: 147-152.

Berner A. H. 1988. Federal pheasants - impact of federal agricultural programs on pheasant habitat 1934-1985. [In: Pheasants: Symptoms of Wildlife Problems on Agricultural Lands. D. L. Hallett, W. R. Edwards and G. V. Burger, eds]. North Central Section of the Wildlife Society, Bloomington, Illinois: $45-94$.

Blake K. and Dowel S. 1993. Gamebirds in set-aside. [In: Game Conservancy Annual Review 1992]. Game Conservancy, Fordingbridge: $56-57$.

Boag B. 1992. Effect of set-aside on soil nematode fauna and vertebrates in Eastern Scotland. [In: BCPC Mono. No. 50 Set-aside. J. Clarke, ed]. British Crop Protection Council, Farnham: 153-158.

Clarke J. (ed) 1992. BCPC Mono. No. 50 Set-aside. British Crop Protection Council, Farnham: 1-283.

Ervin D. 1992. Some lessons about the political-economic effects of set-aside: the United States' experience. [In: BCPC Mono. No. 50 Set-aside. J. Clarke, ed]. British Crop Protection Council, Farnham: 3-12.

Firbank L. G., Arnold H .R., Eversham B. C., Mountford J. O., Radford G. L., Telfer M. G., Treweek J. R., Webb N. R. C. and Wells T. C. E. 1993. Managing set-aside land for wildlife. ITE research publication 7, HMSO, London: 1-146.

Firbank L. G., Telfer M. G., Eversham B. C. and Arnold H. R. 1994. The use of species decline statistics to help target conservation policy for set-aside arable land. Journal of Environmental Management 42: 415-422.

Grynderup Poulsen J. and Sotherton N. 1993. Skylarks on farmland: a species in decline. [In: Game Conservancy Annual Review 1992]. Game Conservancy, Fordingbridge: 58-60.

MAFF 1995. Arable Areas Payments 1995/1996, Explanatory Guide: Parts 1 and 2. MAFF, UK: 1-80.

Plesner Jensen S. and Honess P. 1995. The influence of moonlight on vegetation height preference and trapability of small mammals. Mammalia 59: 35-42.

Rogers L. M. and Gorman M. L. 1995a. The population dynamics of small mammals living in set-aside and surrounding semi-natural and crop land. Journal of Zoology 236: 451-464.

Rogers L. M. and Gorman M. L. 1995b. The diet of the wood mouse Apodemus sylvaticus on set-aside land. Journal of Zoology 235: 77-83.

Rogers L. M. and Gorman M. L. 1995c. The home-range size of wood mice Apodemus sylvaticus living in set-aside and surrounding semi-natural and crop land. Journal of Zoology 235: 77-83.

Sage R. B. and Robertson P. A. 1994. Wildlife and game potential of short rotation coppice in the UK. Biomass and Bioenergy 6: 41-48.

Sears J. 1992. The value of set-aside to birds. [In: BCPC Mono. No. 50 Set-aside. J. Clarke, ed]. British Crop Protection Council, Farnham:175-180.

Smith H. and Macdonald D. W. 1992. The impacts of mowing and sowing on weed populations and species richness in field margin set-aside. [In: BCPC Mono. No. 50 Set-aside. J. Clarke, ed]. British Crop Protection Council, Farnham: 117-122.

Received 2 December 1996, accepted 3 April 1997. 